American Journal of Agricultural and Biological Sciences 5 (4): 486-487, 2010

ISSN 1557-4989

(C) 2010 Science Publications

\title{
A Review on Contributions Presented at the BioMicroWorld2009 Conference
}

\author{
Antonio Mendez-Vilas \\ FORMATEX Research Center, Zurbarán 1, 2-Office 1, 06002 Badajoz, Spain, \\ CIBER-BBN, Microbial Adhesion Group,Department of Applied Physics, \\ University of Extremadura, Avda. Elvas s/n, 06071 Badajoz, Spain
}

\begin{abstract}
BioMicroWorld2009 Conference provides a multi-disciplinary forum bringing together those involved in microbiology from both applied and research communities to present current science and also to discuss and synthesize research priorities and directions for the future. It was the 3rd international conference on environmental, industrial and applied biology. The conference brought together more than 600 researches from about 54 countries involved in microbiology, from both applied and research communities, to identify new approaches and research opportunities in applied microbiology presenting works which linked microbiology with research areas usually related with other scientific and engineering disciplines, as well as to consolidate international collaborative efforts and communicate current research priorities and progress in the field. Biomicro world 2009 conference ended this meeting by concluded that the use of microbes to reduce pollutants and industrial wastes and to change towards a less resource consuming society is being given considerable importance nowadays. New applications of beneficial microorganisms, working for the conservation of soil fertility, the control of plagues and diseases, and the improvement of agricultural productive processes and food industry, are required more and more in the mainframe of an environmental friendly agriculture and society. And science and technology emerging from microbiology research can help meet these challenges.
\end{abstract}

Key words: Research communities, synthesize research, collaborative efforts

\section{INTRODUCTION}

Main areas of interest in Biomicro world 2009 conference which were to explore, Agriculture, Soil, Forest Microbiology Analytical and Imaging Techniques. Microscopy, Environmental, Marine, Aquatic Microbiology. Geomicrobiology, Food Microbiology, Industrial Microbiology-Future Bioindustries, Medical Microbiology-Pharmaceutical Microbiology, Methods- Quantitative Models and Bioinformatics in Microbiology, Microbial Physiology, Metabolism and Gene Expression.

The efficiency of Trichoderma harzianum and Aneurinobacillus migulanus in the control of Gladiolus corm rot in soilless culture system, (Walid et al., 2010). This study evaluates the efficiency of both antagonists against corm rot caused by the fungal phatogen Fusarium oxysporum f. sp. Gladioli, what is a serious problem in gladiolus production, causing huge financial losses to growersChitinolytic Bacteria Isolated from Chili Rhizosphere: Chitinase Characterization and Its Application as Biocontrol for whitefly (Bemisia tabaci Genn.), (Mubarik et al., 2010). This research was conducted to screen chitinolytic rhizobacteria isolated from rhizosphere of chilli pepper and to determine their chitinase activity in degrading chitin (a common constituent of insect exoskeleton) of whitefly, which is an important pesTt on many crops.Use of a Mixture of Thermophilic Enzymes Produced by the Fungus Thermoascus aurantiacus to Enhance the Enzymatic Hydrolysis of the Sugarcane Bagasse Cellulose, (Monte et al., 2010) The present study focuses on the effect of different culture conditions on production of cellulases and hemicellulases by $T$. aurantiacus. It is also provides a possible application of $T$. aurantiacus enzymes in the degradation of sugarcane bagasse pulp, considering that this thermophilic fungus is a potential source of thermostable enzymes.Glomalin production and microbial activity in soils impacted by gypsum mining in the semiarid of Pernambuco, (Mergulhao et al., 2010). This study study the environmental impact produced by the gypsum mining activity in the microbial biomass, the total enzymatic activity and production of glomalin, which can be a useful indicator of soil disturbance.New antifungal bacteriocin-synthesizing strains of Lactococcus lactis ssp. lactis as the perspective biopreservatives for protection of raw smoked 
sausages, (Stoyanova et al., 2010). In this study, it was performed a screening of effective antifungal strains from milk and dairy products and also powerful drinks of mixed lactic acid and alcoholic fermentation, evaluating the effects of the treatment of raw smoked sausages with cultural broth of the strains L. lactis ssp. lactis 194 and K205 against food-born pathogens included fungi.Bioaugmentative Approaches for Dairy Wastewater Treatment, (Schneider et al., ). This study deals with the challenge to achieve high effectiveness of wastewater treatment process in two modules: anaerobic treatment process for dairy wastewater in broadly spread sequencing batch bioreactor with fixed biomass, and selfpurification processes in a water receiver for partially treated dairy wastewater.Genetic and Biochemical Aspects of Ectoine Biosynthesis in Moderately Halophilic and Halotolerant Methylotrophic Bacteria, (Khmelenina et al., 2010).

This study evaluates genetics and enzymatic aspects of the ectoine biosynthesis pathway in aerobic methylotrophic bacteria. Ectoine and its hydroxylated derivative, hydroxyectoine, are powerful multifunctional bioprotectants that defend against a variety of damaging factors such as heating, freezing, desiccation and UV radiation. Both compounds are widely used in medicine and cosmetics as brought-range stabilizers.

We hope readers will find this issue interesting and helpful to their research.

\section{ACKNOWLEDGMENT}

It has been a pleasure to put together this special issue in American Journal of Agriculture and Biological Sciences. We would like to thank all members of the Organizing and Scientific Advisory Committees for the work made during the conference preparation. We would also like to thank all the contributing authors for sharing their knowledge and research, as well as all the reviewers for their advice, which certainly helped to improve the quality, accuracy and relevance of this publication.

\section{REFERENCES}

Khmelenina, V.N., I.I. Mustakhimov, A.S. Reshetnikov, M.G. Kalyuzhnaya and Y.A. Trotsenko, 2010. Genetic and biochemical aspects of ectoine biosynthesis in moderately halophilic and halotolerant methylotrophic bacteria. Am. J. Agric. Biol. Sci., 5: 446-458. DOI: 10.3844/ajabssp.2010.446.458
Mergulhao, A.C.E.S., H.A. Burity, F.S.B. da Silva, S.V. Pereira and L.C. Maia, 2010. Glomalin production and microbial activity in soils impacted by gypsum mining in the semiarid of pernambuco. Am. J. Agric. Biol. Sci., 5: 422-429. DOI: 10.3844/ajabssp.2010.422.429

Monte, J.R., W. Carvalho and A.M.F. Milagres, 2010. Use of a mixture of thermophilic enzymes produced by the fungus thermoascus aurantiacus to enhance the enzymatic hydrolysis of the sugarcane bagasse cellulose. Am. J. Agric. Biol. Scie., 5: 468-476. DOI: 10.3844/ajabssp.2010.468.476

Mubarik, N.R., I. Mahagiani, A. Anindyaputri, S. Santoso and I. Rusmana, 2010. Chitinolytic bacteria isolated from chili rhizosphere: Chitinase characterization and its application as biocontrol for whitefly (bemisia tabaci genn.) Am. J. Agric. Biol. Sci., 5: 430-435. DOI: $10.3844 / a j a b s s p .2010 .430 .435$

Walid, N., M. Jim and W. Steve, 2010 The efficiency of Trichoderma harzianum and Aneurinobacillus migulanus in the control of Gladiolus corm rot in soilless culture system. Am. J. Agric. Biol. Sci., 5: 436-445. DOI: 10.3844/ajabssp.2010.436.445

Schneider, I. et al. Bioaugmentative Approaches for Dairy Wastewater Treatment. Am. J. Agric. Biol. Sci., 5: 459-467. DOI: 10.3844/ajabssp.2010.459.467

Stoyanova, L.G., E.A. Ustyugova, T.D. Sultimova, E.N. Bilanenko and G.B Fedorova et al., 2010. New antifungal bacteriocinsynthesizing strains of Lactococcus lactis ssp. lactis as the perspective biopreservatives for protection of raw smoked sausages. Am. J. Agric. Biol. Sci., 5: 477-485. DOI: 10.3844/ajabssp.2010.477.485 